\title{
Risk factors for requirement of filtration surgery after vitrectomy in patients with proliferative diabetic retinopathy [Corrigendum]
}

\author{
Sakamoto M, Hashimoto R, Yoshida I, Maeno T. Clin \\ Ophthalmol. 2018;12:733-738.
}

Page 733, Abstract, Results section, line 2, the text " $(P=0.08)$ " should read " $(P=0.008)$ ".

Page 735, Table 1, Filtration surgery (-) column, Preoperative IOP, $\mathrm{mmHg}$ row, the text " $15.4 \pm 3.3$ " should read

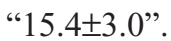

Page 735, Table 1, Filtration surgery (+) column, $\mathrm{HbA}_{1 \mathrm{c}}, \%$ row, the text "7.1 \pm 1.4 " should read " $7.4 \pm 1.7$ ".
Page 735, Table 1, Filtration surgery (-) column, $\mathrm{HbA}_{1 \mathrm{c}}, \%$ row, the text "7.4 \pm 1.7 " should read "7.1 \pm 1.4 ".

Page 735, Table 1, Filtration surgery (+) column, FBG, mg/dL row, the text " $148.0 \pm 39.6$ " should read " $195.9 \pm 72.0$ ".

Page 735, Table 1, Filtration surgery (-) column, FBG, mg/dL row, the text " $195.9 \pm 72.0$ " should read " $148.0 \pm 39.6$ ".
Clinical Ophthalmology

\section{Publish your work in this journal}

Clinical Ophthalmology is an international, peer-reviewed journal covering all subspecialties within ophthalmology. Key topics include: Optometry; Visual science; Pharmacology and drug therapy in eye diseases; Basic Sciences; Primary and Secondary eye care; Patient Safety and Quality of Care Improvements. This journal is indexed on

\section{Dovepress}

PubMed Central and CAS, and is the official journal of The Society of Clinical Ophthalmology (SCO). The manuscript management system is completely online and includes a very quick and fair peer-review system, which is all easy to use. Visit http://www.dovepress.com/ testimonials.php to read real quotes from published authors. 